\title{
植物メタボロミクスの開拓と薬用資源植物ゲノミクスへの展開
}

\author{
齊 藤 和 季 $a, b$
}

\section{Development of Plant Metabolomics and Medicinal Plant Genomics}

\author{
Kazuki Saito ${ }^{a, b}$ \\ ${ }^{a}$ Graduate School of Pharmaceutical Sciences, Chiba University; Inohana 1-8-1, Chuo-ku, Chiba 260-8675, Japan: \\ and ${ }^{b}$ RIKEN Center for Sustainable Resource Science; Suehiro-cho 1-7-22, Tsurumi-ku, Yokohama 230-0045, Japan.
}

(Received August 22, 2017)

\begin{abstract}
A variety of chemicals produced by plants, often referred to as 'phytochemicals', have been used as medicines, food, fuels and industrial raw materials. Recent advances in the study of genomics and metabolomics in plant science have accelerated our understanding of the mechanisms, regulation and evolution of the biosynthesis of specialized plant products. We can now address such questions as how the metabolomic diversity of plants is originated at the levels of genome, and how we should apply this knowledge to drug discovery, industry and agriculture. Our research group has focused on metabolomics-based functional genomics over the last 15 years and we have developed a new research area called 'Phytochemical Genomics'. In this review, the development of a research platform for plant metabolomics is discussed first, to provide a better understanding of the chemical diversity of plants. Then, representative applications of metabolomics to functional genomics in a model plant, Arabidopsis thaliana, are described. The extension of integrated multi-omics analyses to non-model specialized plants, e.g., medicinal plants, is presented, including the identification of novel genes, metabolites and networks for the biosynthesis of flavonoids, alkaloids, sulfur-containing metabolites and terpenoids. Further, functional genomics studies on a variety of medicinal plants is presented. I also discuss future trends in pharmacognosy and related sciences.
\end{abstract}

Key words__ plant genomics; medicinal plant; metabolomics; secondary metabolite; biosynthesis; pharmacognosy

\section{1.はじめに：研究の意義と目的}

植物は, 人類の生存に必須な医薬品, 食料, 工業 原料となる化学的多様性に富んだ代謝産物を生産し ている．植物が生産する代謝産物の総数は 20 万種 と考えられていたが，植物代謝産物の公開デー夕 ベース構築とその統計学的な解析から 100 万種と見 積もられている.1)これは植物代謝産物についての データベース KNApSAck の解析から， 1 植物種あ たりのユニークな成分数が平均 4.76 種であり，そ れに一般に認められている植物種の総数 223000 種 を乗じた推定数である.このように, 膨大な数の植 物化学成分が存在すると考えられ，この植物の持つ 化学的多様性のゲノム基盤の解明とその応用が急務

$a$ 千葉大学大学院薬学研究院（干260-8675 千葉市中央 区亥鼻 1-8-1), b理化学研究所環境資源科学研究セン

ター（下 230-0045 横浜市鶴見区末広町 1-7-22)

e-mail: ksaito@ faculty.chiba-u.jp

本総説は, 平成 29 年度日本薬学会賞の受賞を記念して 記述したものである。
である.

この化学多様性を生み出す原理とその意義を解明 することは, 植物の生存戦略の根源に迫ることがで きるばかりでなく，この原理を応用することによっ て有用な植物代謝産物を合理的な戦略によって生産 することができる．現在までに多くの薬学徒が植物 等の天然資源を薬とする研究を続けてきたが，その 過程で誰しもが「なぜ植物はこんなにも多くの多様 性に富む化学成分を作るのだろう?」「一体どうい う原理で作られて，その植物にとつてどんな意味が あるのだろう?」という疑問を持ったことであろ う。この疑問は多くの研究者に共通する学術的興味 だけでなく，どのように天然資源を薬として使うか という薬学の根源にも及ぶ問題である.

この目的のためには, 網羅的な代謝産物解析に関 するメタボロミクスを基盤としたゲノム機能科学に よって根源的な答えに近づくことができる。つま り，ゲノムやメタボロームレベルでの植物代謝産物 の生産とその制御の原理，その生物における生物学 
的意味，進化の痕跡や道程を明らかにし，その知見 に基づきゲノムに基盤をおいたバイオテクノロジー への道筋を提示することができる。このような根源 的な理解は, 植物科学や薬学分野全体に大きなイン パクトを与え，持続的な薬用資源開発にもつながる.

筆者らは, 過去約 15 年の研究により，世界で初 めてメタボロミクスを中心とした統合オミクスの研 究基盤を構築し，モデル植物シロイヌナズナや薬用 植物・作物に展開して新規で重要な遺伝子，代謝産 物，代謝ネットワークを同定，解明した。 さらに， このように多様な植物代謝をゲノムレベルから理解 し有効利用するための基幹分野である「ファイトケ ミカルゲノミクス」という新しい研究分野を開拓し た.

なお，このようなある植物種や近縁種に特異的な 植物成分は古くから「二次代謝産物」と呼ばれてい るが，この用語はどの生物にも共通に存在する「一 次代謝産物」に対して重要度が低いという間違った 印象を与え易いので，最近ではこの二次代謝産物を 「特異的代謝産物（Specialized metabolites）」と呼 ぶことも多い。これらの二次代謝産物がそれを生産 する植物の進化において極めて重要な役割を果たし てきたことは最近の研究で明らかにされつつあ る. ${ }^{2)}$

\section{2. ファイトケミカルゲノミクスの基本的考え方}

ファイトケミカルゲノミクスは Fig. 1 に示すよ うに，植物成分とその生産に注目したゲノム機能科 学とデー夕駆動型のシステム生物学と捉えることが できる. ${ }^{3)}$ そこでは，ゲノミクス，トランスクリプ トミクスとともにメタボロミクスを統合し，システ ム全体の振る舞いを解析するシステム生物学が大き な役割を占める。ここではシステム生物学は検証可 能な仮説形成ステップとして寄与する．次に，ここ で得られた仮説は逆遺伝学, 逆生化学, 数学的モデ ルを通してゲノム機能科学として検証され，必要な らば仮説の修正を行う。さらに，検証された仮説は 遺伝子組換えや合成生物学，ゲノム編集によってバ イオテクノロジーとして応用される.

このように一貫した基本的コンセプトを確立し， ファイトケミカルゲノミクス研究を推進した。

3.メタボロミクスを中心とした統合オミクスの 基盤構築

ゲノミクス，トランスクリプトミクスは核酸の 4
塩基（4 デジット）で表現できるので，高速化，自 動化は比較的容易であり，特に過去数年は次世代 DNA シークエンサーの発展により少なくともデー 夕取得は簡便にできるようになった。しかし，メ夕 ボロミクスに関してはその情報を格納している代謝 産物が有する化学的性質の多様性と複雑性のため に，核酸の塩基配列決定のような自動化は極めて困 難であり，おそらく今後も不可能であろう。そこ で，まず植物メタボロミクスの基盤技術開発を行 い，各種質量分析装置によるメタボローム解析をゲ ノム，トランスクリプトームと統合して未知遺伝子 の機能を決定する統合オミクス解析の研究プラット フォームを構築した.

具体的には以下の 2 項目の基盤開発を行った.

(i) 高機能質量分析計を用いた植物メタボロー ム分析, ${ }^{4-11)}$ データベース開発, ${ }^{12-14)}$ 代謝産物を同 定するためのピークアノテーション手法, ${ }^{15-17)}$ メ夕 ボロミクスを指向した植物成分の網羅的な単離と同 定, ${ }^{18,19)}$ 単一細胞及びオルガネラにおけるメタボロ ミクス, ${ }^{20,21)}$ などのメタボローム解析の基盤技術開 発22,23)

(ii） メタボロミクスとトランスクリプトミク ス，ゲノミクスを統合して遺伝子と代謝産物を対応 させるゲノム機能科学のための統合オミクス手法の 開発24-31)

ついで，これらの開発したプラットフォームを用 いて，植物におけるゲノム機能科学のための統合才 ミクスを推進し，新規遺伝子機能やネットワークを 同定し，バイオテクノロジ一応用につなげる新手法 の開発と一般化を推進した.

これらは，2000 年に千葉大学で CREST プロ ジェクトとして開始し，さらに 2005 年に理化学研 究所に日本の植物メタボロミクスのナショナルプ ラットフォームとして本格的に立ち上げ，その以降 現在まで継続して世界の最先端プラットフォームと

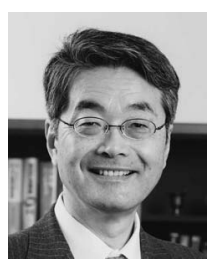

齊藤和季
長野県出身。1977 年東京大学薬学部 卒, 同大学院博士課程中退, 慶應義塾 大学医学部助手, 82 年薬学博士号取 得. ゲント大学留学, 千葉大学薬学部 助手, 講師, 助教授を経て, 95 年同教 授に昇任. 2005 年から理化学研究所グ ループディレクターを兼務，現在副セ ンター長. 専門は, 生薬学, 植物ゲノ ム機能科学，植物バイオテクノロジー. 


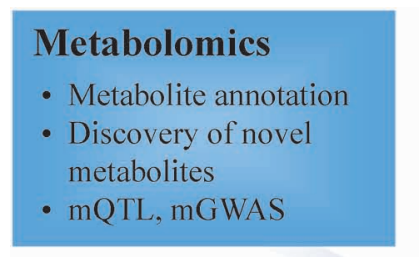

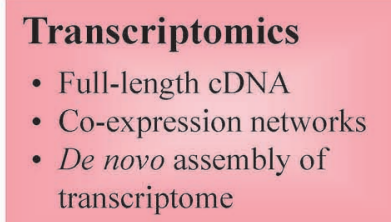

transcriptome

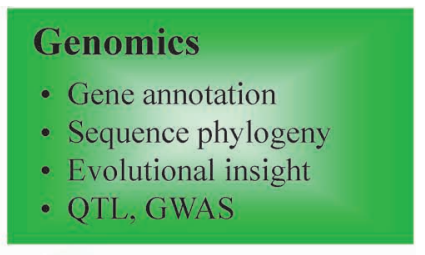

Data processing, databasing, integration

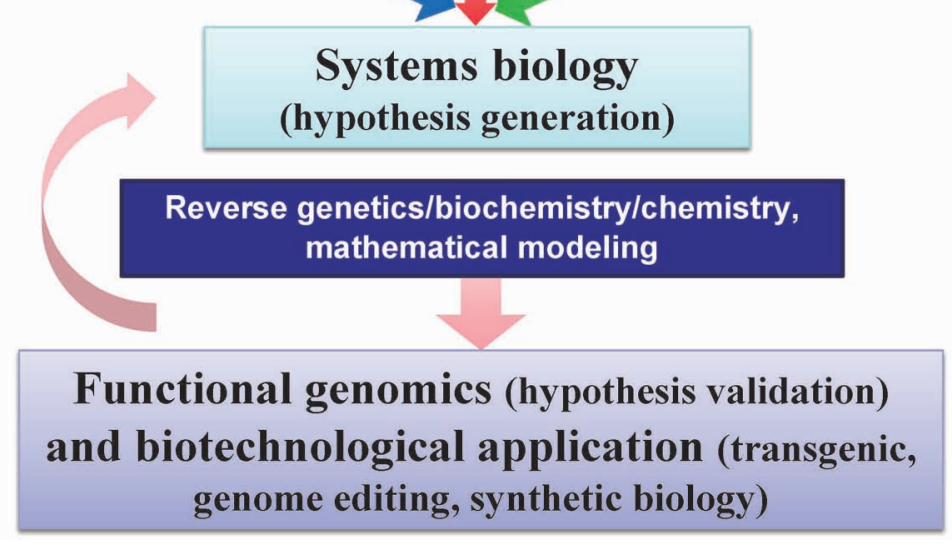

Fig. 1. Data-driven Systems Biology and Functional Genomics

して機能し, 研究コミュニティにも提供している. これを用いて，下記に述べるようにシロイヌナズナ や薬用植物, 作物のゲノム機能科学（未知遺伝子や 新規代謝産物の同定，代謝物一遺伝子ネットワーク の解明）に適用して, 多くの新規遺伝子や代謝産物 の発見につながつた. ${ }^{22,23,32-35)}$

4. モデル植物シロイヌナズナにおけるメタボロ ミクスとゲノム機能科学

アブラナ科の一年草シロイヌナズナ (Arabidopsis thaliana）は，高等植物の中ではゲノムサイズが小 さく, 一世代が短く室内栽培が簡単で多数の種子が 採れる，形質転換が容易であるなどの理由で，植物 分子生物学のモデル植物として広く基礎研究に用い られている．2000 年 12 月には高等植物として初め て全ゲノム配列が解読された. ${ }^{36)}$

このようにゲノム配列が解読されたことにより, 従来の変異体の形質からその変異遺伝子を同定する 順（行）遺伝学に対して，ゲノム上の配列だけが分 かつている機能未知遺伝子から，その遺伝子が規定 する形質を解析することによって遺伝子機能を同定 する逆（行）遺伝学が可能になつた。この逆遺伝学 の効率的な実現には，ゲノム配列に加えて，遺伝子 アノテーション, 全遺伝子についての挿入変異体パ
ネル，全遺伝子の完全長 cDNA コレクション，及 びそれらのデータベースなどが必要であるが，幸い なことに日本も含めた国際的なシロイヌナズナ研究 コミュニティの努力によって，2000 年以降これら の公共的な研究リソースが揃えられた。 そこで，こ のシロイヌナズナを用いてメタボロミクスを基盤と した統合ゲノム機能科学研究を推進した. ${ }^{29,37)}$

4-1. シロイヌナズナにおける硫黄代謝系の遺伝 子機能同定 硫黄を含んだ植物成分は特異な生物 活性を有するものが多く，また植物細胞においても 重要な役割を果たしている. ${ }^{38,39)}$ そこで，硫黄代謝 系の新規遺伝子，制御ネットワーク及び制御機構を ゲノムワイドに同定した。

硫黄同化や代謝系に重要な遺伝子として，ゲノム 上に複数個存在する硫酸イオントランスポー ター, ${ }^{40-45)}$ セリンアセチル転移酵素, ${ }^{46-50)}$ システイ ン合成酵素及び同族の $\beta$-シアノアラニン合成酵 素, ${ }^{51-53)}$ ATP スルフリラーゼ, ${ }^{54,55)}$ APS キナー ゼ, 56) グルタチオン関連代謝酵素, ${ }^{57,58)}$ セリン合成 酵素59-62)などを主にシロイヌナズナから同定し，そ の機能や制御をメタボロミクスと組み合わせること により世界に先駆けて解明した．また，硫黄同化と 同時にグルコシノレートなど含硫黄代謝産物の分解 
を制御する転写因子63) やマイクロ $\mathrm{RNA}^{64,65)}$ など硫 黄代謝に係わる新規な分子制御因子の同定にも成功 した.

硫黄代謝に係わる個別の遺伝子の機能解明のほか に，硫黄欠乏下でのトランスクリプトームとメタボ ローム解析 ${ }^{66,67)}$ やプロテオーム解析 ${ }^{68)}$ など統合オミ クス研究を進めた。このような統合解析からグルコ シノレート生合成の酵素遺伝子69,70) や制御に係わる MYB 転写因子71) や新規制御因子 ${ }^{72)}$ の同定を行っ た。またこのように得られた硫黄代謝系に関与す る遺伝子を用いた有用植物の作出 ${ }^{73-75)}$ など薬学的な 展開を図った。

4-2. シロイヌナズナでのフラボノイドの構造多 様性を決定している生合成遺伝子多様性の解明

フラボノイドはグルコシノレートとならび，シロ イヌナズナにおける代表的な二次代謝産物である. シロイヌナズナのフラボノイドとしてはアントシア ニン, フラボノール，プロアントシアニジンなどが 知られている. ${ }^{18,76)}$

まず，単一の MYB 転写因子が過剩発現し，アン トシアニンが高蓄積している機能獲得型変異体のト ランスクリプトミクスとメタボロミクスによって, アントシアニン生産に係わるゲノム遺伝子候補を包 括的にリスト化した。次に，これらの候補遺伝子の ノックアウト変異体の代謝産物解析によって当該遺 伝子の機能を同定することに成功した. ${ }^{77)}$

さらにこの手法をより一般化して，シロイヌナズ ナの公共的なトランスクリプトームデータ78) から遺 伝子共発現ネットワークを解析して，フラボイド生 合成遺伝子群のモジュールを抽出し，そのネット ワークモジュールに含まれる遺伝子の欠失変異体の 代謝産物解析から多くのフラボイド生合成遺伝子の 機能を決定した. ${ }^{29,79-87)}$ その結果，フラボノイドの 基本骨格の生合成遺伝子のみならず，構造的多様性 に寄与する修飾酵素遺伝子群（配糖化酵素，アシル 転移酵素など）の機能をほぼすべて同定することが できた.

これにより，シロイヌナズナにおけるフラボノイ ドの構造的多様性と遺伝子多様性を統一的に議論す ることが可能になつた. ${ }^{76,88)}$ これは高等植物で初め て二次代謝産物の化学構造の多様性の根源であるゲ ノム多様性を解明した歴史的な成果である。ささ に，同定した遺伝子や変異体を用いて抗酸化活性な
どを増強した有用形質付与植物の作出などバイオテ クノロジーに応用した. ${ }^{89-92)}$

4-3. シロイヌナズナでのその他の代謝系遺伝子 の機能同定とネットワーク解明＼cjkstart環境ストレスな どの非生物学的ストレス下（硫黄やリンなどの栄養 欠乏，紫外線, ${ }^{91,93)}$ 乾燥, 94) 低温, ${ }^{95)}$ 高温96) など) や代謝系遺伝子の変異体 ${ }^{97-101)}$ でのメ夕ボローム解 析から，新規遺伝子，新規代謝産物，新規代謝ネッ

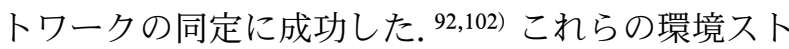
レスによってある種のアミノ酸，糖，フェニルプロ パノイド，フラボノイド生産が誘導され，それぞれ のストレス緩和機能を有することを実験的に明らか にした.

特に，脂質メタボロミクスを応用して，葉緑体で の含硫黄脂質生合成に特異的に関与する新規配糖化 酵素を同定したこと103)や，リン久乏に応答して誘 導されリン欠乏緩和機能を有する新規なグルクロン 酸脂質を発見し，その生合成経路と遺伝子群を同定 したこと, 104-107) 高温ストレス下での脂質リモデリ ングを解明したこと ${ }^{96)}$ などが特筆すべき成果として 挙げられる．これらは植物の生存にとって最も重要 な環境ストレス耐性の新たな分子メカニズムの発見 である.さらに，時計遺伝子変異体でのメタボロー ム解析から生物時計とミトコンドリア代謝の密接な 相互作用を解明した. ${ }^{35,108)}$

\section{5. 薬用資源植物や作物におけるメタボロミクス} とゲノム機能科学

植物科学の基礎的な研究はモデル植物であるシロ イヌナズナを用いることによって最も効率的に推進 できる．しかし，薬学的な応用を目指した研究は， 実際に薬用として用いられている薬用資源植物や重 要な作物において研究する必要がある。 そこで, 上 記のシロイヌナズナで開発したゲノム機能科学の手 法を，薬用資源植物や重要作物に応用して，多くの 重要な遺伝子の機能を同定し，さらにバイオテクノ ロジーに応用した。

5-1. 世界で初めてのトランスジェニック薬用植 物の作出逆遺伝学的手法によって遺伝子機能を 同定するためには，その遺伝子を有する植物におい て当該遺伝子を破壊したり，過剩発現した植物を作 出する必要がある。また，薬用成分の生産制御など のバイオテクノロジー応用にも，遺伝子組換えした トランスジェニック薬用植物を作出する技術の確立 
が必須である．筆者らは，1990 年代からアグロバ クテリウム-Ti 又は Ri プラスミド系を使って，世 界で初めてトランスジェニック（遺伝子組換え）薬 用植物の作出に成功した。109-111)これらは，甘 草, 112) ジギタリス, 113) ベラドンナ, 114) Scoparia dulcis, ${ }^{115)}$ シソ, ${ }^{116)}$ チャボイナモリ117)などの薬用植 物にモデル遺伝子や除草剤耐性遺伝子を導入発現し た研究であり，その後大きく展開した薬用資源植物 における代謝エンジニアリングやゲノム研究の重要 な基盤となっている.

\section{5-2. シソでのアントシアニン生合成シソ} (Perilla frutescens var. crispa) の葉及び枝先は生薬 ソヨウ（紫蘇葉，蘇葉）として漢薬や民間薬，食品 として広く用いられている. 主成分はアントシアニ ンやロズマリン酸などのポリフェノール類，モノテ ルペンを主とする精油が知られている.

シソにはアントシアニンを生産する赤ジソと生産 しない青ジソという成分変種が知られている。 そこ で，赤ジソ，青ジソを用いて，アントシアニンの生 合成酵素遺伝子118,119) や転写制御因子120-123) を網羅 的にクローニングし，それらの遺伝子機能を解析し た. ${ }^{124)}$ 特に，赤ジソ，青ジソについて，その発現 に差のある遺伝子フラグメントを網羅的に同定でき る mRNA ディファレンシャル発現解析 ${ }^{125-127)} に$ よって，新規のアントシアニン 5- $O$-配糖化酵素遺 伝子128,129) を単離することができた。これが契機と なり，その後他の植物種130,131) からも同様の遺伝子 を単離することができた。 また，アントシアニンの 発色段階に関与するアントシアニジン合成酵素遺伝 子を単離し，その組換えタンパク質の酵素活性を初 めて in vitro で検出することに成功し, ${ }^{132,133)}$ 発色段 階の生化学的な機構解明を計算化学も含めて詳細に

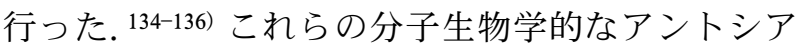
ニン生合成研究は，さらに赤ジソ，青ジソのメタボ ローム解析 ${ }^{137)}$ や次世代シークエンサーによる

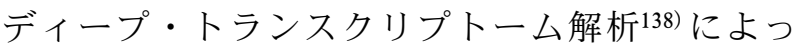
て，より統一的に理解できる段階に来ている.

5-3. カンプトテシン生合成と自己耐性機構 臨床的に用いられている抗がん成分カンプトテシ ン生産機構についてもゲノム機能科学によりいくつ かの新発見をした.

まず，カンプトテシン生産性が安定的に良好なア カネ科チャボイナモリ（Ophiorrhiza pumila）と類
縁植物（O. liukiuensis, O. kuroiwai）の毛状根培養 細胞を前述のアグロバクテリウム-Ri プラスミド系 により確立した. ${ }^{117,139,140)}$ この毛状根細胞から, 力 ンプトテシン生合成に関与するいくつかの酵素遺伝 子を単離する141,142) とともに，バイオリアクターで の生産系 ${ }^{140)}$ や毛状根細胞からのチャボイナモリ植 物の再分化系も確立した. ${ }^{143)}$ さらに， ${ }^{13} \mathrm{C}$ で標識し たグルコースを用いたトレーサー実験によって，カ ンプトテシンはいわゆる非メバロン酸経路である MEP 経路由来のセコイリドイドとシキミ酸経路由 来のトリプタミンの複合経路によって生合成される

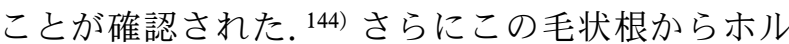
モン処理によってカンプトテシン生産性がほとんど みられない懸濁培養細胞系を確立し，遺伝的には同 一なカンプトテシン生産細胞（毛状根）と非生産細 胞（懸濁培養）について，代謝産物のターゲット解 析, ${ }^{145)}$ メタボローム及びトランスクリプトーム解 析 ${ }^{146)}$ を行った。このように二次代謝産物の生産細 胞と非生産細胞でのディファレンシャル発現解析 は，生合成関連遺伝子の同定に非常に有力な手段で ある。特に，このチャボイナモリのケースでは PCR-セレクトサブトラクションと次世代シークエ ンサーによる RNA-Seq 解析 ${ }^{146)}$ が有効であり，生合 成に係わる 2 個の新規転写因子をコードする遺伝子 を同定した. ${ }^{147,148)}$ また，チャボイナモリ毛状根は 二次代謝産物としてカンプトテシンのようなモノテ ルペノイドインドールアルカロイドだけでなく，ア ントラキノン類, クロロゲン酸などの二次代謝成分 も生産するが，これらの生合成候補遺伝子も同定す ることができた. ${ }^{146)}$

このように統合オミクスから絞り込んだ生合成候 補遺伝子の機能同定のためには，RNA 干渉による 当該遺伝子のノックダウンが有効である. 特に, チャボイナモリにおいて二次代謝生合成系を負に制 御する MYB 転写因子147) や，正に制御する AP2/ ERF 転写因子 148$)$ の機能を組換え毛状根を用いた RNA 干渉によって in vivo で決定することができ た. また，カンプトテシン生合成の初発段階に係わ るトリプトファン脱炭酸酵素遺伝子を RNA 干渉に よってノックダウンしたチャボイナモリ毛状根か ら，生合成中間体あるいは代謝産物と考えられる未 知成分ピークを高速液体クロマトグラフィーーフー リエ変換イオンサイクロトロン質量分析計（LC- 
FT/ICR-MS）によるメタボローム解析によって検 出することができた. ${ }^{149)}$

カンプトテシンはすべての真核細胞の核に存在す る DNA トポイソメラーゼ I に作用し，その活性を 阻害して細胞分裂を止め抗がん活性を発揮する。し たがって，カンプトテシンを生産する植物細胞は, このカンプトテシンの毒性に対する自己耐性機構を 備えているはずである。このような毒性成分に対す る植物の自己耐性機構としては，特異的な輸送機構 によるターゲット分子からの隔離などいくつかの機 構が知られていた。 ${ }^{150)}$ そこで，カンプトテシンの 細胞内外での輸送と隔離なども検討したが, ${ }^{151)}$ 最 終的にカンプトテシンに対する自己耐性を付与する 機構としてターゲット分子である DNA トポイソメ ラーゼ I の点突然変異を発見した. ${ }^{152)}$ この突然変異 は，トポイソメラーゼ I による酵素反応の中間体で あるニックの入った DNA と共有結合を形成する活 性中心残基に隣接する一アミノ酸残基アスパラギン からセリンへの変異であった，さらに，驚くべきこ とに全く同じ変異がカンプトテシンに対して耐性と なったヒトの白血病細胞にも見つかっていたのであ る. ${ }^{153)}$ 詳しい研究の結果, この保存性の高いアス パラギンからセリンへの変異は DNA トポイソメ ラーゼ I の酵素活性を維持しながら，カンプトテシ ンとトポイソメラーゼ I との水素結合が形成され ず，その結果カンプトテシンー酵素-DNA の三者複 合体が形成できないため耐性を付与する唯一の変異 であった. ${ }^{152,153)}$ この変異は，アカネ科及びチャボ イナモリ属の内外を含めて，カンプトテシンを生産 する植物種にはかならず起こっており，同属の近縁 種も含めて生産しない植物種にはみられないとい う, カンプトテシン生産性との極めて厳格な対応関

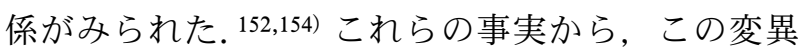
が自己耐性に必須であり，カンプトテシン生産能力 と自己耐性能の獲得が密接に共進化したという植物 二次代謝の遺伝子進化について新しい仮説を提唱す ることができた. ${ }^{153,155)}$ さらに計算化学によって別 の変異も含めた DNA トポイソメラーゼ I の構造と カンプトテシン毒性について理論的な考察を行つ

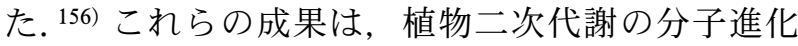
学的な解明のみならず，将来の抗がん薬の開発や薬 剂耐性メカニズムの解明にもつながる発見である.
5-4. キノリチジンアルカロイド生合成 生薬 苦参（クジン）の主要成分マトリンに代表されるマ 义科植物のキノリチジンアルカロイドに関する化学 的研究は, 日本の薬学の祖である長井長義博士によ る最初の報告 ${ }^{157)}$ 以来, 日本の薬学の重要な研究 テーマであった. ${ }^{158,159)}$ 筆者らは村越千葉大学名誉 教授らが先駆的に開拓したこのマメ科植物キノリチ ジンアルカロイドに関する植物生理学及び化学分類 学研究160,161) 継続しながら，苦参の基原植物クラ ラ（Sophora flavescens）の組織培養によるマトリ ンの生産 ${ }^{162)}$ などバイオテクノロジー研究も推進し た。 その結果，マメ科ルピナス属植物を用いて，ア シル型キノリチジンアルカロイドの生合成に係わる アルカロイドアシル転移酵素の精製163,164) と分子ク ローニング165)が世界で初めて成功した.

これらの生化学的なアプローチに加え，ルピナス （Lupinus angustifolia）のアルカロイドを含む成分 変種と含まない成分変種を用いた分子生物学的なア プローチも取り入れた。アルカロイド成分パター ン166) と遺伝学的及び生化学的マーカーの解析 ${ }^{167,168)}$ から始まり，ついで遺伝子発現のディファレンシャ ル解析を行った。このアルカロイドを含むビター種 と含まないスイート種の遺伝子発現のディファレン シャル解析から，アルカロイド生産に関連している と予想される複数の遺伝子断片を得ることができ た．それらの断片配列のアノテーションから，さら に候補遺伝子を絞り込み，完全長のcDNAを得 た。 その結果，L. angustifolia からキノリチジンア ルカロイド生合成の初発段階を触媒し, リジンから カダベリンを生成するリジン脱炭酸酵素遺伝子を初 めて単離した. ${ }^{169)}$ さらに，クララやイヌクララな どの他のキノリチジンアルカロイド含有植物からも 同様にリジン脱炭酸酵素遺伝子をクローン化した.

これらは一次代謝のポリアミンの生産に関与するオ ルニチン脱炭酸酵素が変異した酵素と考えられ，活 性中心の基質結合キャビティの大きさを決定する一 アミノ酸残基の変異がリジン脱炭酸活性に必須であ

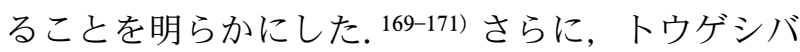
などのリジンーカダベリン由来アルカロイドを生産 する遠縁の植物のリジン脱炭酸酵素においても，こ の重要なアミノ酸変異は保存されていた. ${ }^{172)} さ ら ら$ に, 進化学的な計算からこの変異は正の選択圧を受 けていることを証明し，遠縁植物におけるアルカロ 
イド生産遺伝子の収斂進化を実証した。 ${ }^{172,173)} ま$ た，単離したリジン脱炭酸酵素遺伝子を用いてタバ コ毛状根においてアナバシン生産などリジン由来ア

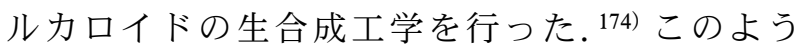
に, クララでのマトリン生合成の初発段階に係わる 遺伝子を解明できたと考えている. 長井博士以来の 日本の薬学における中心テーマの末端に係わり, 分 子生物学的なアプローチで少しでも新しい展開に貢 献できたことは望外の喜びである.

5-5. 含硫黄二次代謝成分の生合成亡分解 含 硫黄植物成分の生合成研究は, 既に述べたようにシ ロイヌナズナでの研究がその基盤となっているが, モデル植物であるシロイヌナズナでのゲノム研究を 開始する以前に，ホウレンソウからのシステイン合 成酵素 cDNA を世界で初めてクローン化したのが

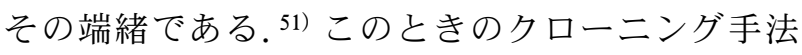
は，精製した酵素タンパク質の部分アミノ酸配列を 微量分析法によって決定し，その配列を基に合成し た縮重 DNA プローブを用いての cDNA ライブラ リーのスクリーニングであった。 その後, 大腸菌の 変異体を用いた遺伝的相補によるスクリーニングも 活用した.これらの手法によりホウレンソウからの 局在性の異なるシステイン合成酵素や $\beta$-シアノア ラニン合成酵素 cDNA, ${ }^{51,52,175-178)}$ システイン合成だ けでなく $\beta$-置換アラニン類の生合成にも関与する スイカ酵素の cDNA, ${ }^{179,180)}$ さらにセリンアセチル 転移酵素 $\mathrm{cDNA}^{46,181-183)}$ などを単離した。このよう に植物の硫黄同化及びシステイン生合成研究の分子 生物学研究を世界に先駆けて開拓し, 後のシロイヌ ナズナでのゲノム機能科学研究につなげた.

含硫黄性の二次代謝成分の生合成や代謝について は，ニンニク，タマネギ，二ラなどのヒガンバナ科 ネギ属植物に多く含まれ, 特徵的な生物活性を有す る香辛性成分であるアリインなどアルキル（アルケ ニル）システインスルフォキシドの生合成や代謝に ついて分子生物学的な知見を得た。研究の初期には アリインを分解して香気成分を生成する段階に関与 するアリナーゼ cDNA を単離し, ${ }^{184)}$ その性質を調 べるとともに植物での局在性を明らかにした。 ${ }^{185)}$ さらに最近，アリイン生合成の鍵反応に関与する $\gamma$-グルタミルトランスペプチダーゼ186) とスルフォ キシド生成を触媒するフラビン含有型酸素添加酵 素187) cDNA をニンニクからクローニングするこ
とに成功し, 生合成反応の詳細が解明されつつある.

また，超高分解能の FT-ICR/MS を用いた網羅的 な含硫黄成分の解析法（S-オミクス）を開発 し, ${ }^{10,188)}$ その手法をヒガンバナ科ネギ属植物の含硫 黄成分の網羅的プロファイリングに応用した。 ${ }^{189)}$ さらに，この手法を用いてアスパラガスから血圧降 下作用が期待される新規の含硫黄代謝産物（アスパ ラプチンと命名）の単離と同定にも成功した。 ${ }^{190)}$ また，シロイヌナズナでの研究を基にして, ${ }^{71)}$ 同じ アブラナ科ケールでのグルコシノレート生合成制御 因子の同定と機能解析も行った. ${ }^{191)}$

含硫黄植物成分は多くの場合特徽的な生物活性を 有しており, 特異な生合成機構や酵素によるものが 多く, 二次代謝産物の生合成の環境適応と進化の観 点から興味深いテーマとなる.

5-6. 甘草（カンゾウ）でのグリチルリチン生合 成 甘草は七割以上の漢方処方に配合されてお り，その主要甘味成分であるグリチルリチンには抗 炎症作用や肝機能改善作用など多くの薬理活性が報 告されている. 甘草に関する研究の初期には甘草根 からの DNA 抽出と DNA 判別167) やウラルカンゾウ (Glycyrrhiza uralensis) 毛状根への外来遺伝子導 入112) 研究した. その後, 甘草のゲノム研究を全 日本レベルの研究コンソーシアムを組織, 主導し て, 多くの方々との共同研究として推進した. 甘草 の基原植物であるウラルカンゾウの完全長 cDNA ライブラリーを作製し，それぞれのcDNA クロー ンの端読み配列データである expressed sequence $\operatorname{tag}(\mathrm{EST})$ データベースを作成した. ${ }^{192)}$ それらを 基にして, 複数のシトクローム P450 遺伝子を抽出 し, その発現パターンがグリチルリチンの蓄積とよ く相関するクローンをグリチルリチン生合成遺伝子 候補として，その機能を証明した。 その結果, トリ テルペノイドの共通中間体である $\beta$-アミリンから グリチルリチンのアグリコンであるグリチルレチン 酸生合成に至る 2 つシトクローム P450 遺伝子を 同定し, ${ }^{193,194)}$ 同時に組換え酵母でグリチルレチン

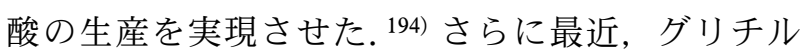
リチン含有量の異なる複数のウラルカンゾウ品種と 組織の RNA-Seq 解析を行い, ${ }^{195)}$ ついでドラフトゲ

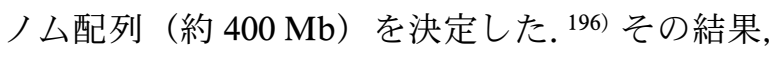
甘草の薬効成分の 1 つであるイソフラボノイドの生 合成に係わる 3 個の酵素遺伝子がゲノム上でクラス 
ター化して存在していることが明らかになつた. ${ }^{196)}$ これは漢方にも用いられる生薬基原植物での初めて のゲノム配列決定の快挙であり，今後の甘草におけ る基礎研究とバイオテクノロジ一応用の基盤になる 成果である。

5-7. 広範な薬用資源植物のゲノム科学 前述 したように興味深い二次代謝産物を含むいくつかの 薬用植物について，そのゲノム機能科学の基礎研究 としてディープ・トランスクリプトーム解析やゲノ ム解析を行ったが，さらに最近は広範に多くの薬用 植物について組織的なゲノム関連解析を行つている.

RNA-Seq 解析によるトランスクリプトミクス は，前述のシソ, 138) チャボイナモリ, 146) ウラルカ ンゾウ195)に加え，クズ (Pueraria lobata), 197) クラ ラ (Sophora flavescens $),{ }^{198)}$ トチバニンジン $(\mathrm{Pa}$ nax japonicus), ${ }^{199)}$ センブリ (Swertia japonica), ${ }^{200)}$ ホオズキ (Physalis alkekengi)，201) スイカズラ (Lonicera japonica)，202)レンギョウ（Forsythia suspensa), トリカブト (Aconitum sp.), サンシュ ユ (Cornus officinalis)（いずれも投稿準備中）な どについて終了又は進行中である。これらのトラン スクリプトーム解析は，それぞれの薬用部位を含む 複数部位の解析に加え, 可能な限り成分パターンの 異なる近縁種の RNA-Seq データやメタボローム データも統合して，それぞれに特異的な薬効成分の 生合成や代謝, 輸送に関する遺伝子候補を絞り込ん でいる.

また，ゲノム配列解析は前述のウラル甘草のゲノ ム配列決定 ${ }^{196)}$ に続き，現在，スペインカンゾウ， 新疆カンゾウ，チャボイナモリ，シナニッケイなど のゲノム配列決定を進めている.これらの薬用植物 のゲノム科学は将来の生薬学や薬用植物学の分野に おいて重要な研究基盤となると確信している. ${ }^{203,204)}$

5-8. イネなどの重要作物でのゲノム機能科学 メタボロミクスを基盤とした植物のゲノム機能科 学研究は, 薬用植物やその有効成分の生合成研究に 留まらず，広く農作物などにも展開することが重要 と考えられる。イネのバイオリソース（完全長 cDNA 発現体，コアコレクション，組換え自殖系 統，特定遺伝子破壊など）のメタボローム解析を系 統的に行い, 8,19,23,205-210) 窒素代謝と二次代謝を制御 している新規遺伝子の同定, ${ }^{205,211,212)}$ イネの形質と 関連する代謝産物や遺伝子の同定, ${ }^{213,214)}$ アミノ酸
生合成遺伝子や代謝ネットワークの役割, 215-217) 代 謝産物を決定する量的形質遺伝子座（QTL）の同 定, ${ }^{218,219)}$ メ夕ボローム・ゲノムワイド関連解析 (GWAS), ${ }^{220)}$ 形態形成やストレス応答 $\left.221-225\right)$ など, 薬学的観点からのイネ充種や有用性への分子レベル での知見を得た.

また，メタボローム解析を遺伝子組換えトマ 卜226) や遺伝子組換えダイズ227)の実質的同等性の評 価に応用するなど，実用的及び社会的な問題につい ても取り組んでいる.

\section{6. 本研究の国際的研究コミュニティへの貢献と 今後の期待}

幸いにして本研究は，メタボロミクスを中心とし た植物ゲノム機能科学研究として国際的な研究コ ミュニティにおいて客観的な指標から高く評価され た。特に，2004 年と 2005 年に出版した 2 報の論 文 ${ }^{67,77)}$ は，それぞれの翌年の植物バイオテクノロ ジー分野の最高被引用論文として連続して Nature

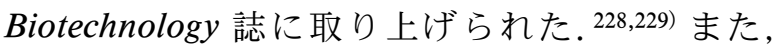
2007 年に $P N A S$ に発表した論文 ${ }^{71)}$ はトムソン・ロ イター社の Fast Breaking Papers-2008 として表彰 された. ${ }^{230)}$ さらに筆者は 3 年連続 $(2014,2015$, 2016 年）してトムソン・ロイター社（現・Clarivate Analytics 社)が選定した Highly Cited Researchers（植物・動物学分野）の一人に選ばれた。 ${ }^{231)}$ ま た，2010 年及び 2015 年には米国生物学会（American Society of Plant Biologists; ASPB) が, 同学会 の 2 つの学術雑誌に過去 5 年間に出版された論文の 被引用度調査から最も影響の大きな研究者として選 定した ASPB TOP AUTHORS に連続して選ばれ

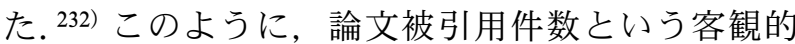
な指標から, 本研究が国際的な研究社会から評価さ れ，その発展に大きく貢献したことが分かる.

さて，以上の研究成果から今後どのような展開が 可能であろうか？ 以下に私見を述べたい，

前述したように植物が生産する代謝産物の総数は 20 万種から 100 万種と推定されているが，各種の データベース登録数や生物活性プロジェクトでの研 究成果に基づく筆者の推定によると，そのうち約 $10 \%$ の植物種の化学成分や生物活性が調べられてい るにすぎない。 したがって，残りの $90 \%$ の植物種 の生物活性成分の探索は今後の重要な課題である. 2015 年のノーベル生理学医学賞に輝いたクソニン 


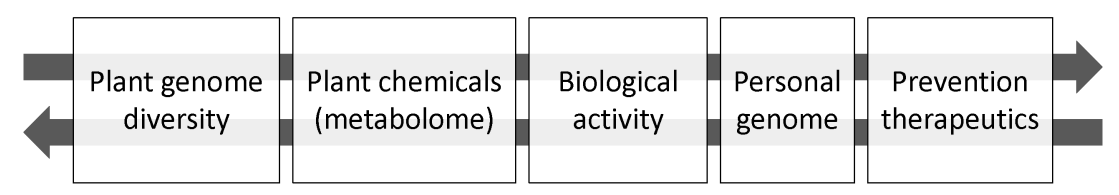

Fig. 2. Concept of Coherent Network from Plant Genome to Prevention and Therapeutics through Plant Metabolome, Biological Activity and Personal Genome

ジンからの抗マラリア薬アルテミニシンの発見に は，中国の古典も寄与しており伝承医薬的な知識の

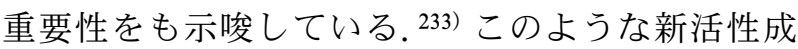
分の探索にも非ターゲット型のメタボロミクス研究 が貢献できる. ${ }^{34,190)}$

2016 年末時点でゲノム配列が報告されている植 物は 200 種足らずであり，そのうち約 20 種が薬用

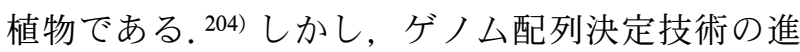
歩は非常に急速であり，数年後には多くの薬用植物 のゲノム配列が決定されていると思われる。 そうす ると，既にイネで行われたように, 220) メタボロミ クスと組み合わせたメタボローム GWAS 解析に よって，二次代謝産物の生産に必要なゲノム領域を 容易に同定できるようになる。それによって現在は ゲノムサイズの小さな微生物で成功しているゲノム マイニング手法 ${ }^{234)}$ による生合成遺伝子の同定が, 今後ゲノムサイズが巨大な植物ゲノムでも可能にな ると期待される．特に，植物ゲノムにおいても二次 代謝産物の生合成関連遺伝子がゲノム上でクラス ターを形成している例が多く報告されてきてお り, 196,235-237) ゲノム配列からの未知の生合成遺伝子 の予測と同定が今後一層加速すると思われる.

さらに，このように新規に同定されたゲノム遺伝 子を利用したバイオテクノロジーへの応用が期待で きる. ${ }^{238)}$ 従来型の外来遺伝子の導入発現ではある が生合成経路を構成する一連の複数遺伝子を組み合 わせたコンビナトリアル生合成による実用的な物質 生産の試み239)や，最近注目を集めているゲノム編 集技術による生合成経路の改変 240,241$)$ などが期待さ れる．また，植物によらず微生物を宿主とした植物 二次代謝産物の生産のための合成生物学的なアプ ローチも期待される。酵母でのアルテミシニン前駆

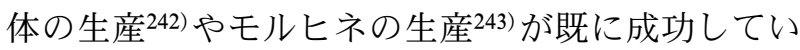
る. 今後, 多くの稀少で高価な植物成分の工業生産 や，複数の遺伝子を組み合わせたコンビナトリアル 生合成による新規成分の生産が酵母などの微生物を
宿主とした合成生物学によって実現できる可能性が ある.

その際，海外の植物資源から化学成分やその遺伝 子を探索する研究は，資源提供国との間で，遺伝資 源の取得とその公正かつ衡平な利益配分について定 めた名古屋議定書 ${ }^{244)}$ に則つて行う必要がある。そ のためにも植物多様性が豊富な資源提供国との国際 連携がますます重要である点も指摘しておきたい.

最後に薬学及び生薬学・医療薬学的な観点からも 展望を述べてみたい，生薬や漢方は多くの化学成分 からなる混合物を医薬として用いて，ヒトの病態を かならずしも個別要素や分子に還元せずむしろこれ を全体として捉え，システム全体として予防や治療 を試みるところに特徵がある．われわれ人類はこれ らの経験的な知恵を数千年に渡り暗黙知として蓄積 してきたと見なすことができる，その暗黙知を現代 的な言葉での形式知に変換しようとする試みが, 生 薬学や漢方医療学という学問であるとも言える。一 方，ゲノムも地球に誕生した生命が 30 数億年の間 に蓄積してきた暗黙知であり，これを形式知に読み 解こうとする試みがゲノム科学である。このように 考えると暗黙知から形式知への解読とその原理への 昇華は共通した作業であると言える。したがって, 生薬として用いる植物のゲノム情報からはじまり, それらを用いての個別のゲノムを有する個人の予 防・治療を一貫した軸で考えることが可能であろう (Fig. 2)。この，(1)植物ゲノム，(2)植物からの混合 成分 (生薬义タボローム)，(3)それが示す生物活性 スペクトル，(4)予防・治療すべきヒトの個人ゲノム, (5)最終的な予防・治療効果, という5つのモジュー ルに対して一貫した情報ネットワークを構築できれ ば，個人の健康・疾患に対して最適な予防・治療効 果を与える生薬の組み合わせを，植物ゲノムまで落 とし込んで特定することができるはずである。これ はまさしく個人のテーラーメイド医薬を，植物ゲノ ムまで遡って多様な化学成分からなる植物医薬とし 
てデザインし，予防や治療に供給できることにな る. 実は，このような方向の研究は生薬の組み合わ せである漢方医薬の情報学的解析から部分的に試み られ始めている. ${ }^{245)}$ 今後, このような方向に発展 するためには, 植物ゲノム多様性や生薬メ夕ボロー ム，その生物活性スペクトルなどのデー夕蓄積が必 須であることは言うまでもない。 さらに，個人のゲ ノム解析の一般化とともに, 急速に発展している人 工知能 (AI) の導入によってこの方向は確実に加 速すると期待される.

7. おわりに

以上のように, 本研究成果は, 植物由来の薬用成 分の夕ならず，植物の有する化学的多様性の根源的 理解とそのバイオテクノロジー研究に大きく貢献 し, 将来の生薬学や天然資源系薬学の方向性をも提 示する. 今後, 植物成分としてだけでなく, 植物の 有効利用によって地球的規模で人類が直面している 健康, 食料, 環境に関する根本的な諸問題の解決に 植物科学が大きく寄与することが期待されてい る. ${ }^{2)}$

謝辞本研究は, 千葉大学大学院薬学研究院遺 伝子資源応用研究室及び理化学研究所環境資源科学 研究センター統合メタボロミクス研究グループを中 心とする国内外の共同研究者により遂行されたもの です。これらのすべての共同研究者の皆様に感謝申 し上げます。

利益相反 開示すべき利益相反はない.

\section{REFERENCES}

1) Afendi F. M., Okada T., Yamazaki M., HiraiMorita A., Nakamura Y., Nakamura K., Ikeda S., Takahashi H., Altaf-Ul-Amin M., Darusman L. K., Saito K., Kanaya S., Plant Cell Physiol., 53, e1 (2012).

2) Saito K., "Shokubutsu wa Naze Kusuri o Tsukurunoka," Bungeishunju Ltd., Tokyo, 2017.

3) Saito K., Curr. Opin. Plant Biol., 16, 373-380 (2013).

4) Suzuki H., Sasaki R., Ogata Y., Nakamura Y., Sakurai N., Kitajima M., Takayama H., Kanaya S., Aoki K., Shibata D., Saito K.,
Phytochemistry, 69, 99-111 (2008) .

5) Matsuda F., Yonekura-Sakakibara K., Niida R., Kuromori T., Shinozaki K., Saito K., Plant J., 57, 555-577 (2009).

6) Nakabayashi R., Tsugawa H., Kitajima M., Takayama H., Saito K., Front. Plant Sci., 6, 1127 (2015).

7) Nakabayashi R., Saito K., Anal. Bioanal. Chem., 405, 5005-5011 (2013).

8) Kusano M., Fukushima A., Kobayashi M., Hayashi N., Jonsson P., Moritz T., Ebana K., Saito K., J. Chromatogr. B: Anal. Technol. Biomed. Life Sci., 855, 71-79 (2007).

9) Okazaki Y., Kamide Y., Hirai M., Saito K., Metabolomics, 9, 121-131 (2013).

10) Nakabayashi R., Sawada Y., Yamada Y., Suzuki M., Hirai M. Y., Sakurai T., Saito K., Anal. Chem., 85, 1310-1315 (2013).

11) Nakabayashi R., Hashimoto K., Toyooka K., Saito K., Anal. Chem., 89, 2698-2703 (2017).

12) Horai H., Arita M., Kanaya S., Nihei Y., Ikeda T., Suwa K., Ojima Y., Tanaka K., Tanaka S., Aoshima K., Oda Y., Kakazu Y., Kusano M., Tohge T., Matsuda F., Sawada Y., Hirai M. Y., Nakanishi H., Ikeda K., Akimoto N., Maoka T., Takahashi H., Ara T., Sakurai N., Suzuki H., Shibata D., Neumann S., Iida T., Funatsu K., Matsuura F., Soga T., Taguchi R., Saito K., Nishioka T., J. Mass Spectrom., 45, 703-714 (2010).

13) Sawada Y., Nakabayashi R., Yamada Y., Suzuki M., Sato M., Sakata A., Akiyama K., Sakurai T., Matsuda F., Aoki T., Hirai M. Y., Saito K., Phytochemistry, 82, 38-45 (2012).

14) Kind T., Okazaki Y., Saito K., Fiehn O., Anal. Chem., 86, 11024-11027 (2014).

15) Matsuda F., Shinbo Y., Oikawa A., Hirai M. Y., Fiehn O., Kanaya S., Saito K., PLoS One, 4, e7490 (2009).

16) Tsugawa H., Kind T., Nakabayashi R., Yukihira D., Tanaka W., Cajka T., Saito K., Fiehn O., Arita M., Anal. Chem., 88, 7946-7958 (2016) .

17) Nakabayashi R., Tsugawa H., Mori T., Saito K., Metabolomics, 12, 168 (2016).

18) Nakabayashi R., Kusano M., Kobayashi M., Tohge T., Yonekura-Sakakibara K., Kogure N., Yamazaki M., Kitajima M., Saito K., Takayama H., Phytochemistry, 70, 1017-1029 
(2009) .

19) Yang Z., Nakabayashi R., Okazaki Y., Mori T., Takamatsu S., Kitanaka S., Kikuchi J., Saito K., Metabolomics, 10, 543-555 (2014).

20) Oikawa A., Matsuda F., Kikuyama M., Mimura T., Saito K., Plant Physiol., 157, 544-551 (2011).

21) Oikawa A., Saito K., Plant J., 70, 30-38 (2012).

22) Okazaki Y., Saito K., Plant Biotechnol. Rep., 6, 1-15 (2012).

23) Okazaki Y., Saito K., GigaScience, 5, 11 (2016) .

24) Akiyama K., Chikayama E., Yuasa H., Shimada Y., Tohge T., Shinozaki K., Hirai M. Y., Sakurai T., Kikuchi J., Saito K., In Silico Biol., 8, 339-345 (2008).

25) Sakurai N., Ara T., Ogata Y., Sano R., Ohno T., Sugiyama K., Hiruta A., Yamazaki K., Yano K., Aoki K., Aharoni A., Hamada K., Yokoyama K., Kawamura S., Otsuka H., Tokimatsu T., Kanehisa M., Suzuki H., Saito K., Shibata D., Nucleic Acids Res., 39, D677D684 (2011).

26) Sakurai T., Yamada Y., Sawada Y., Matsuda F., Akiyama K., Shinozaki K., Hirai M. Y., Saito K., Plant Cell Physiol., 54, e5 (2013).

27) Matsuda F., Hirai M. Y., Sasaki E., Akiyama K., Yonekura-Sakakibara K., Provart N. J., Sakurai T., Shimada Y., Saito K., Plant Physiol., 152, 566-578 (2010).

28) Morioka R., Kanaya S., Hirai M. Y., Yano M., Ogasawara N., Saito K., BMC Bioinformatics, 8, 343 (2007).

29) Saito K., Hirai M. Y., Yonekura-Sakakibara K., Trends Plant Sci., 13, 36-43 (2008).

30) Fukushima A., Kusano M., Mejia R. F., Iwasa M., Kobayashi M., Hayashi N., WatanabeTakahashi A., Narisawa T., Tohge T., Hur M., Wurtele E. S., Nikolau B. J., Saito K., Plant Physiol., 165, 948-961 (2014).

31) Yano M., Kanaya S., Altaf-Ul-Amin M., Kurokawa K., Hirai M. Y., Saito K., J. Comput. Aided Chem., 7, 125-136 (2006).

32) Saito K., Matsuda F., Ann. Rev. Plant Biol., 61, 463-489 (2010).

33) Kusano M., Saito K., J. Plant Biochem. Biotechnol., 21, 24-31 (2012).

34) Sumner L. W., Lei Z., Nikolau B. J., Saito K.,
Nat. Prod. Rep., 32, 212-229 (2015) .

35) Fukushima A., Kusano M., Redestig H., Arita M., Saito K., Curr. Opin. Chem. Biol., 13, 532-538 (2009).

36) Arabidopsis Genome Initiative, Nature (London), 408, 796-815 (2000).

37) Nakabayashi R., Yamazaki M., Saito K., New Biotechnol., 27, 829-836 (2010).

38) Saito K., Plant Physiol., 136, 2443-2450 (2004) .

39) Takahashi H., Kopriva S., Giordano M., Saito K., Hell R., Ann. Rev. Plant Biol., 62, 157-184 (2011).

40) Takahashi H., Watanabe-Takahashi A., Smith F. W., Blake-Kalff M., Hawkesford M. J., Saito K., Plant J., 23, 171-182 (2000) .

41) Yoshimoto N., Takahashi H., Smith F. W., Yamaya T., Saito K., Plant J., 29, 465-743 (2002).

42) Yoshimoto N., Inoue E., Saito K., Yamaya T., Takahashi H., Plant Physiol., 131, 15111517 (2003).

43) Awazuhara M., Fujiwara T., Hayashi H., Watanabe-Takahashi A., Takahashi H., Saito K., Physiol. Plant., 125, 95-105 (2005) .

44) Yoshimoto N., Inoue E., Watanabe-Takahashi A., Saito K., Takahashi H., Plant Physiol., 145, 378-388 (2007).

45) Maruyama-Nakashita A., Watanabe-Takahashi A., Inoue E., Yamaya T., Saito K., Takahashi H., Plant Cell, 27, 1279-1296 (2015).

46) Saito K., Yokoyama H., Noji M., Murakoshi I., J. Biol. Chem., 270, 16321-16326 (1995).

47) Noji M., Inoue K., Kimura N., Gouda A., Saito K., J. Biol. Chem., 273, 32739-32745 (1998).

48) Noji M., Takagi Y., Kimura N., Inoue K., Saito M., Horikoshi M., Saito F., Takahashi H., Saito K., Plant Cell Physiol., 42, 627-634 (2001).

49) Kawashima C. G., Berkowitz O., Hell R., Noji M., Saito K., Plant Physiol., 137, 220230 (2005).

50) Watanabe M., Mochida K., Kato T., Tabata S., Yoshimoto N., Noji M., Saito K., Plant Cell, 20, 2484-2496 (2008).

51) Saito K., Miura N., Yamazaki M., Hirano H., Murakoshi I., Proc. Natl. Acad. Sci. USA, 89, 
8078-8082 (1992).

52) Hatzfeld Y., Maruyama A., Schmidt A., Noji M., Ishizawa K., Saito K., Plant Physiol., 123, 1163-1171 (2000).

53) Watanabe M., Kusano M., Oikawa A., Fukushima A., Noji M., Saito K., Plant Physiol., 146, 310-320 (2008).

54) Hatzfeld Y., Lee S., Lee M., Leustek T., Saito K., Gene, 248, 51-58 (2000) .

55) Bohrer A.-S., Yoshimoto N., Sekiguchi A., Rykulski N., Saito K., Takahashi H., Front. Plant Sci., 5, 750 (2015).

56) Mugford S. G., Yoshimoto N., Reichelt M., Wirtz M., Hill L., Mugford S. T., Nakazato Y., Noji M., Takahashi H., Kramell R., Gigolashvili T., Flügge U. I., Wasternack C., Gershenzon J., Hell R., Saito K., Kopriva S., Plant Cell, 21, 910-927 (2009) .

57) Ohkama-Ohtsu N., Oikawa A., Zhao P., Xiang C., Saito K., Oliver D. J., Plant Physiol., 148, 1603-1613 (2008).

58) Ohkama-Ohtsu N., Sasaki-Sekimoto Y., Oikawa A., Jikumaru Y., Shinoda S., Inoue E., Kamide Y., Yokoyama T., Hirai M. Y., Shirasu K., Kamiya Y., Oliver D. J., Saito K., Plant Cell Physiol., 52, 205-209 (2011).

59) Ho C. L., Noji M., Saito K., J. Biol. Chem., 274, 11007-11012 (1999).

60) Ho C. L., Noji M., Saito M., Saito K., J. Biol. Chem., 274, 397-402 (1999).

61) Ho C. L., Noji M., Saito M., Yamazaki M., Saito K., Plant J., 16, 443-452 (1998).

62) Ho C. L., Saito K., Amino Acids, 20, 243-259 (2001).

63) Maruyama-Nakashita A., Nakamura Y., Tohge T., Saito K., Takahashi H., Plant Cell, 18, 3235-3251 (2006).

64) Kawashima C. G., Yoshimoto N., MaruyamaNakashita A., Tsuchiya Y. N., Saito K., Takahashi H., Dalmay T., Plant J., 57, 313-321 (2009) .

65) Kawashima C. G., Matthewman C. A., Huang S., Lee B. R., Yoshimoto N., Koprivova A., Rubio-Somoza I., Todesco M., Rathjen T., Saito K., Takahashi H., Dalmay T., Kopriva S., Plant J., 66, 863-876 (2011).

66) Hirai M. Y., Fujiwara T., Awazuhara M., Kimura T., Noji M., Saito K., Plant J., 33, 651-663 (2003).
67) Hirai M. Y., Yano M., Goodenowe D. B., Kanaya S., Kimura T., Awazuhara M., Arita M., Fujiwara T., Saito K., Proc. Natl. Acad. Sci. USA, 101, 10205-10210 (2004).

68) Higashi Y., Hirai M. Y., Fujiwara T., Naito S., Noji M., Saito K., Plant J., 48, 557-571 (2006).

69) Hirai M. Y., Klein M., Fujikawa Y., Yano M., Goodenowe D. B., Yamazaki Y., Kanaya S., Nakamura Y., Kitayama M., Suzuki H., Sakurai N., Shibata D., Tokuhisa J., Reichelt M., Gershenzon J., Papenbrock J., Saito K., J. Biol. Chem., 280, 25590-25595 (2005) .

70) Sawada Y., Kuwahara A., Nagano M., Narisawa T., Sakata A., Saito K., Yokota Hirai M., Plant Cell Physiol., 50, 1181-1190 (2009) .

71) Hirai M. Y., Sugiyama K., Sawada Y., Tohge T., Obayashi T., Suzuki A., Araki R., Sakurai N., Suzuki H., Aoki K., Goda H., Nishizawa O. I., Shibata D., Saito K., Proc. Natl. Acad. Sci. USA, 104, 6478-6483 (2007).

72) Aarabi F., Kusajima M., Tohge T., Konishi T., Gigolashvili T., Takamune M., Sasazaki Y., Watanabe M., Nakashita H., Fernie A. R., Saito K., Takahashi H., Hubberten H. M., Hoefgen R., Maruyama-Nakashita A., Sci. $A d v .$, 2, e1601087 (2016).

73) Noji M., Saito M., Nakamura M., Aono M., Saji H., Saito K., Plant Physiol., 126, 973-980 (2001).

74) Kawashima C. G., Noji M., Nakamura M., Ogra Y., Suzuki K. T., Saito K., Biotechnol. Lett., 26, 153-157 (2004).

75) Nakamura M., Ochiai T., Noji M., Ogura Y., Suzuki K. T., Yoshimoto N., Yamazaki M., Saito K., Plant Biotechnol., 31, 141-147 (2014).

76) Saito K., Yonekura-Sakakibara K., Nakabayashi R., Higashi Y., Yamazaki M., Tohge T., Fernie A. R., Plant Physiol. Biochem., 72, 2134 (2013).

77) Tohge T., Nishiyama Y., Hirai M. Y., Yano M., Nakajima J., Awazuhara M., Inoue E., Takahashi H., Goodenowe D. B., Kitayama M., Noji M., Yamazaki M., Saito K., Plant J., 42, 218-235 (2005).

78) Goda H., Sasaki E., Akiyama K., MaruyamaNakashita A., Nakabayashi K., Li W., Ogawa 
M., Yamauchi Y., Preston J., Aoki K., Kiba

T., Takatsuto S., Fujioka S., Asami T., Nakano T., Kato H., Mizuno T., Sakakibara H., Yamaguchi S., Nambara E., Kamiya Y., Takahashi H., Hirai M. Y., Sakurai T., Shinozaki K., Saito K., Yoshida S., Shimada Y., Plant J., 55, 526-542 (2008).

79) Tohge T., Yonekura-Sakakibara K., Niida R., Watanabe-Takahashi A., Saito K., Pure Appl. Chem., 79, 811-823 (2007).

80) Yonekura-Sakakibara K., Tohge T., Niida R., Saito K., J. Biol. Chem., 282, 14932-14941 (2007).

81) Yonekura-Sakakibara K., Tohge T., Matsuda F., Nakabayashi R., Takayama H., Niida R., Watanabe-Takahashi A., Inoue E., Saito K., Plant Cell, 20, 2160-2176 (2008).

82) Kitamura S., Matsuda F., Tohge T., Yonekura-Sakakibara K., Yamazaki M., Saito K., Narumi I., Plant J., 62, 549-559 (2010).

83) Yonekura-Sakakibara K., Fukushima A., Nakabayashi R., Hanada K., Matsuda F., Sugawara S., Inoue E., Kuromori T., Ito T., Shinozaki K., Wangwattana B., Yamazaki M., Saito K., Plant J., 69, 154-167 (2012) .

84) Yonekura-Sakakibara K., Fukushima A., Saito K., Curr. Opin. Biotechnol., 24, 285-290 (2013).

85) Yonekura-Sakakibara K., Nakabayashi R., Sugawara S., Tohge T., Ito T., Koyanagi M., Kitajima M., Takayama H., Saito K., Plant J., 79, 769-782 (2014).

86) Luo J., Nishiyama Y., Fuell C., Taguchi G., Elliott K., Hill L., Tanaka Y., Kitayama M., Yamazaki M., Bailey P., Parr A., Michael A. J., Saito K., Martin C., Plant J., 50, 678-695 (2007).

87) Wangwattana B., Koyama Y., Nishiyama Y., Kitayama M., Yamazaki M., Saito K., Plant Biotechnol., 25, 191-196 (2008).

88) Yonekura-Sakakibara K., Saito K., Nat. Prod. Rep., 26, 1466-1487 (2009) .

89) Tohge T., Matsui K., Ohme-Takagi M., Yamazaki M., Saito K., Biotechnol. Lett., 27, 297-303 (2005) .

90) Nakabayashi R., Yonekura-Sakakibara K., Urano K., Suzuki M., Yamada Y., Nishizawa T., Matsuda F., Kojima M., Sakakibara H.,
Shinozaki K., Michael A. J., Tohge T., Yamazaki M., Saito K., Plant J., 77, 367-379 (2014) .

91) Tohge T., Wendenburg R., Ishihara H., Nakabayashi R., Watanabe M., Sulpice R., Hoefgen R., Takayama H., Saito K., Stitt M., Fernie A. R., Nat. Commun., 7, 12399 (2016) .

92) Nakabayashi R., Saito K., Curr. Opin. Plant Biol., 24, 10-16 (2015).

93) Kusano M., Tohge T., Fukushima A., Kobayashi M., Hayashi N., Otsuki H., Kondou Y., Goto H., Kawashima M., Matsuda F., Niida R., Matsui M., Saito K., Fernie A. R., Plant J., 67, 354-369 (2011).

94) Urano K., Maruyama K., Ogata Y., Morishita Y., Takeda M., Sakurai N., Suzuki H., Saito K., Shibata D., Kobayashi M., YamaguchiShinozaki K., Shinozaki K., Plant J., 57, 1065-1078 (2009).

95) Maruyama K., Takeda M., Kidokoro S., Yamada K., Sakuma Y., Urano K., Fujita M., Yoshiwara K., Matsukura S., Morishita Y., Sasaki R., Suzuki H., Saito K., Shibata D., Shinozaki K., Yamaguchi-Shinozaki K., Plant Physiol., 150, 1972-1980 (2009).

96) Higashi Y., Okazaki Y., Myouga F., Shinozaki K., Saito K., Sci. Rep., 5, 10533 (2015) .

97) Kusano M., Fukushima A., Arita M., Jonsson P., Moritz T., Kobayashi M., Hayashi N., Tohge T., Saito K., BMC Syst. Biol., 1, 53 (2007).

98) Kusano M., Fukushima A., Redestig H., Kobayashi M., Otsuki H., Onouchi H., Naito S., Hirai M. Y., Saito K., Amino Acids, 39, 1013-1021 (2010).

99) Diaz C., Kusano M., Sulpice R., Araki M., Redestig H., Saito K., Stitt M., Shin R., BMC Syst. Biol., 5, 192 (2011).

100) Satou M., Enoki H., Oikawa A., Ohta D., Saito K., Hachiya T., Sakakibara H., Kusano M., Fukushima A., Saito K., Kobayshi M., Nagata N., Myouga F., Shinozaki K., Motohashi R., Plant Mol. Biol., 85, 411-428 (2014).

101) Fukushima A., Iwasa M., Nakabayashi R., Kobayashi M., Nishizawa T., Okazaki Y., Saito K., Kusano M., Front. Plant Sci., 8, 
1464 (2017).

102) Fukushima A., Kusano M., Redestig H., Arita M., Saito K., BMC Syst. Biol., 5, 1 (2011).

103) Okazaki Y., Shimojima M., Sawada Y., Toyooka K., Narisawa T., Mochida K., Tanaka H., Matsuda F., Hirai A., Hirai M. Y., Ohta H., Saito K., Plant Cell, 21, 892-909 (2009) .

104) Okazaki Y., Otsuki H., Narisawa T., Kobayashi M., Sawai S., Kamide Y., Kusano M., Aoki T., Hirai M. Y., Saito K., Nat. Commun., 4, 1510 (2013).

105) Okazaki Y., Saito K., Plant J., 79, 584-596 (2014).

106) Okazaki Y., Nishizawa T., Takano K., Ohnishi M., Mimura T., Saito K., Physiol. Plant., 155, 33-42 (2015).

107) Okazaki Y., Takano K., Saito K., Plant Biotechnol., 34, 57-63 (2017).

108) Fukushima A., Kusano M., Nakamichi N., Kobayashi M., Hayashi N., Sakakibara H., Mizuno T., Saito K., Proc. Natl. Acad. Sci. USA, 106, 7251-7256 (2009).

109) Saito, K., Yakugaku Zasshi, 114, 1-20 (1994).

110) Saito K., Yamazaki M., Kaneko H., Murakoshi I., Fukuda Y., Van Montagu M., Planta, 184, 40-46 (1991).

111) Saito K., Yamazaki M., Murakoshi I., J. Nat. Prod., 55, 149-162 (1992).

112) Saito K., Kaneko H., Yamazaki M., Yoshida M., Murakoshi I., Plant Cell Rep., 8, 718-721 (1990).

113) Saito K., Yamazaki M., Shimomura K., Yoshimatsu K., Murakoshi I., Plant Cell Rep., 9, 121-124 (1990) .

114) Saito K., Yamazaki M., Anzai H., Yoneyama K., Murakoshi I., Plant Cell Rep., 11, 219-224 (1992).

115) Yamazaki M., Son L., Hayashi T., Morita N., Asamizu T., Mourakoshi I., Saito K., Plant Cell Rep., 15, 317-321 (1996).

116) Yamazaki M., Kobayashi M., Saito K., Plant Biotechnol., 14, 169-173 (1997).

117) Saito K., Sudo H., Yamazaki M., KosekiNakamura M., Kitajima M., Takayama H., Aimi N., Plant Cell Rep., 20, 267-271 (2001).

118) Gong Z., Yamazaki M., Sugiyama M., Tanaka Y., Saito K., Plant Mol. Biol., 35, 915-927 (1997).

119) Kitada C., Gong Z., Tanaka Y., Yamazaki
M., Saito K., Plant Cell Physiol., 42, 13381344 (2001).

120) Gong Z. Z., Yamagishi E., Yamazaki M., Saito K., Plant Mol. Biol., 41, 33-44 (1999).

121) Gong Z. Z., Yamazaki M., Saito K., Mol. Gen. Genet., 262, 65-72 (1999) .

122) Gong Z.-Z., Yamazaki M., Saito K., Plant Biotechnol., 17, 309-314 (2000).

123) Sompornpailin K., Makita Y., Yamazaki M., Saito K., Plant Mol. Biol., 50, 485-495 (2002).

124) Saito K., Yamazaki M., New Phytol., 155, 923 (2002).

125) Yamazaki M., Saito K., Cell. Mol. Life Sci., 59, 1246-1255 (2002).

126) Yamazaki M., Shibata M., Nishiyama Y., Springob K., Kitayama M., Shimada N., Aoki T., Ayabe S., Saito K., FEBS J., 275, 34943502 (2008).

127) Yamazaki M., Saito K., Nat. Prod. Commun., 6, 423-427 (2011).

128) Yamazaki M., Gong Z., Fukuchi-Mizutani M., Fukui Y., Tanaka Y., Kusumi T., Saito K., J. Biol. Chem., 274, 7405-7411 (1999) .

129) Yamazaki M., Saito K., Methods Mol. Biol., 317, 255-266 (2006).

130) Yamazaki M., Yamagishi E., Gong Z., Fukuchi-Mizutani M., Fukui Y., Tanaka Y., Kusumi T., Yamaguchi M., Saito K., Plant Mol. Biol., 48, 401-411 (2002).

131) Springob K., Nakajima J., Yamazaki M., Saito K., Nat. Prod. Rep., 20, 288-303 (2003).

132) Saito K., Kobayashi M., Gong Z., Tanaka Y., Yamazaki M., Plant J., 17, 181-189 (1999).

133) Nakajima J., Tanaka Y., Yamazaki M., Saito K., Plant Biotechnol., 17, 331-335 (2000) .

134) Nakajima J., Tanaka Y., Yamazaki M., Saito K., J. Biol. Chem., 276, 25797-25803 (2001) .

135) Turnbull J. J., Nakajima J., Welford R. W., Yamazaki M., Saito K., Schofield C. J., J. Biol. Chem., 279, 1206-1216 (2004).

136) Nakajima J., Sato Y., Hoshino T., Yamazaki M., Saito K., J. Biol. Chem., 281, 2138721398 (2006).

137) Yamazaki M., Nakajima J., Yamanashi M., Sugiyama M., Makita Y., Springob K., Awazuhara M., Saito K., Phytochemistry, 62, 987-995 (2003) . 
138) Fukushima A., Nakamura M., Suzuki H., Saito K., Yamazaki M., PLoS One, 10, e0129154 (2015).

139) Asano T., Watase I., Sudo H., Kitajima M., Takayama H., Aimi N., Yamazaki M., Saito K., Plant Biotechnol., 21, 275-281 (2004).

140) Sudo H., Yamakawa T., Yamazaki M., Aimi N., Saito K., Biotechnol. Lett., 24, 359-363 (2002).

141) Yamazaki Y., Sudo H., Yamazaki M., Aimi N., Saito K., Plant Cell Physiol., 44, 395-403 (2003).

142) Yamazaki M., Asano T., Yamazaki Y., Sirikantaramas S., Sudo H., Saito K., Pure Appl. Chem., 82, 213-218 (2010).

143) Watase I., Sudo H., Yamazaki M., Saito K., Plant Biotechnol., 21, 337-342 (2004).

144) Yamazaki Y., Kitajima M., Arita M., Takayama H., Sudo H., Yamazaki M., Aimi N., Saito K., Plant Physiol., 134, 161-170 (2004).

145) Yamazaki Y., Urano A., Sudo H., Kitajima M., Takayama H., Yamazaki M., Aimi N., Saito K., Phytochemistry, 62, 461-470 (2003) .

146) Yamazaki M., Mochida K., Asano T., Nakabayashi R., Chiba M., Udomson N., Yamazaki Y., Goodenowe D. B., Sankawa U., Yoshida T., Toyoda A., Totoki Y., Sakaki Y., Gongora-Castillo E., Buell C. R., Sakurai T., Saito K., Plant Cell Physiol., 54, 686-696 (2013).

147) Rohani E. R., Chiba M., Kawaharada M., Asano T., Oshima Y., Mitsuda N., OhmeTakagi M., Fukushima A., Rai A., Saito K., Yamazaki M., Plant Biotechnol., 33, 1-9 (2016).

148) Udomsom N., Rai A., Suzuki H., Okuyama J., Imai R., Mori T., Nakabayashi R., Saito K., Yamazaki M., Front. Plant Sci., 7, 1861 (2016).

149) Asano T., Kobayashi K., Kashihara E., Sudo H., Sasaki R., Iijima Y., Aoki K., Shibata D., Saito K., Yamazaki M., Phytochemistry, 91, 128-139 (2013).

150) Sirikantaramas S., Yamazaki M., Saito K., Phytochem. Rev., 7, 467-477 (2008).

151) Sirikantaramas S., Sudo H., Asano T., Yamazaki M., Saito K., Phytochemistry, 68, 2881-2886 (2007).

152) Sirikantaramas S., Yamazaki M., Saito K.,
Proc. Natl. Acad. Sci. USA, 105, 6782-6786 (2008).

153) Sirikantaramas S., Yamazaki M., Saito K., Phytochemistry, 70, 1894-1898 (2009).

154) Viraporn V., Yamazaki M., Saito K., Denduangboripant J., Chayamarit K., Chuanasa T., Sukrong S., Planta Med., 77, 759-764 (2011).

155) Sirikantaramas S., Yamazaki M., Saito K., "Natural Products: Discourse, Diversity, and Design,', ed. by Osbourn A., Goss R. J., Carter G. T., Wiley-Blackwell, Oxford, 2014, pp. 67-82.

156) Sirikantaramas S., Meeprasert A., Rungrotmongkol T., Fuji H., Hoshino T., Sudo H., Yamazaki M., Saito K., Phytochemistry, 113, 50-56 (2015).

157) Nagai N., Yakugaku Zasshi, 54-87 (1889).

158) Okuda S., "Ochiai Eiji Sensei Kaisoroku," ed. by Okamoto T., Hirokawa Shoten, Tokyo, 1992, pp. 211-234.

159) Murakoshi I., "Yakugaku to Tomoni 65 Nen -Tsuda Kyosuke Sensei 85 sai Kinen Bunshu,", ed. by Ikekawa N., Sato Y., Iwasaki S., Hirokawa Shoten, Tokyo, 1992, pp. 143-162.

160) Ohmiya S., Saito K., Murakoshi I., The Alkaloids, 47, 1-114 (1995).

161) Ohmiya S., Saito K., Murakoshi I., Yakugaku Zasshi, 120, 923-934 (2000).

162) Saito K., Yamazaki M., Yamakawa K., Fujisawa S., Takamatsu S., Kawaguchi A., Murakoshi I., Chem. Pharm. Bull., 37, 30013004 (1989).

163) Saito K., Suzuki H., Takamatsu S., Murakoshi I., Phytochemistryl, 32, 87-91 (1992).

164) Suzuki H., Murakoshi I., Saito K., J. Biol. Chem., 269, 15853-15860 (1994).

165) Okada T., Hirai M. Y., Suzuki H., Yamazaki M., Saito K., Plant Cell Physiol., 46, 233-244 (2005).

166) Saito K., Koike Y., Suzuki H., Murakoshi I., Phytochemistry, 34, 1041-1044 (1993).

167) Yamazaki M., Sato A., Shimomura K., Inoue K., Ebizuka Y., Murakoshi I., Saito K., Natural Medicines, 49, 488-490 (1995).

168) Hirai M. Y., Suzuki H., Yamazaki M., Saito K., Chem. Pharm. Bull., 48, 1458-1461 (2000) .

169) Bunsupa S., Katayama K., Ikeura E., Oikawa 
A., Toyooka K., Saito K., Yamazaki M., Plant Cell, 24, 1202-1216 (2012).

170) Bunsupa S., Yamazaki M., Saito K., Front. Plant Sci., 3, 239 (2012).

171) Bunsupa S., Saito K., Yamazaki M., "Biotechnology for Medicinal Plants," ed. by Chandra S., Lata H., Varma A., Springer, Heidelberg, 2013, pp. 263-273.

172) Bunsupa S., Hanada K., Maruyama A., Aoyagi K., Komatsu K., Ueno H., Yamashita M., Sasaki R., Oikawa A., Saito K., Yamazaki M., Plant Physiol., 171, 2432-2444 (2016) .

173) Bunsupa S., Yamazaki M., Saito K., MiniRev. Med. Chem., 12, 1002-1012 (2017).

174) Bunsupa S., Komastsu K., Nakabayashi R., Saito K., Yamazaki M., Plant Biotechnol., 31, 511-518 (2014) .

175) Saito K., Tatsuguchi K., Murakoshi I., Hirano H., FEBS Lett., 324, 247-252 (1993).

176) Saito K., Tatsuguchi K., Takagi Y., Murakoshi I., J. Biol. Chem., 269, 2818728192 (1994).

177) Takahashi H., Saito K., Plant Physiol., 112, 273-280 (1996).

178) Maruyama A., Saito K., Ishizawa K., Plant Mol. Biol., 46, 749-760 (2001).

179) Noji M., Murakoshi I., Saito K., Biochem. Biophys. Res. Commun., 197, 1111-1117 (1993) .

180) Noji M., Murakoshi I., Saito K., Mol. Gen. Genet., 244, 57-66 (1994).

181) Inoue K., Noji M., Saito K., Eur. $J$. Biochem., 266, 220-227 (1999).

182) Urano Y., Manabe T., Noji M., Saito K., Gene, 257, 269-277 (2000) .

183) Saito K., Inoue K., Fukushima R., Noji M., Gene, 189, 57-63 (1997).

184) Manabe T., Hasumi A., Sugiyama M., Yamazaki M., Saito K., Eur. J. Biochem., 257, 21-30 (1998) .

185) Yamazaki M., Sugiyama M., Saito K., Plant Biotechnol., 19, 7-10 (2002).

186) Yoshimoto N., Yabe A., Sugino Y., Murakami S., Sai-Ngam N., Sumi S., Tsuneyoshi T., Saito K., Front. Plant Sci., 5, 758 (2014).

187) Yoshimoto N., Onuma M., Mizuno S., Sugino Y., Nakabayashi R., Imai S., Tsuneyoshi T., Sumi S., Saito K., Plant J., 83, 941-951 (2015).
188) Nakabayashi R., Saito K., Curr. Opin. Biotechnol., 43, 8-16 (2017).

189) Nakabayashi R., Sawada Y., Aoyagi M., Yamada Y., Hirai M. Y., Sakurai T., Kamoi T., Rowan D. D., Saito K., J. Nutr., 146, 397S-402S (2016).

190) Nakabayashi R., Yang Z., Nishizawa T., Mori T., Saito K., J. Nat. Prod., 78, 1179-1183 (2015).

191) Araki R., Hasumi A., Nishizawa O. I., Sasaki K., Kuwahara A., Sawada Y., Totoki Y., Toyoda A., Sakaki Y., Li Y., Saito K., Ogawa T., Hirai M. Y., Plant Biotechnol. J., 11, 1017-1027 (2013).

192) Sudo H., Seki H., Sakurai N., Suzuki H., Shibata D., Toyoda A., Totoki Y., Sakaki Y., Iida O., Shibata T., Kojoma M., Muranaka T., Saito K., Plant Biotechnol., 26, 105-107 (2009).

193) Seki H., Ohyama K., Sawai S., Mizutani M., Ohnishi T., Sudo H., Akashi T., Aoki T., Saito K., Muranaka T., Proc. Natl. Acad. Sci. USA, 105, 14204-14209 (2008).

194) Seki H., Sawai S., Ohyama K., Mizutani M., Ohnishi T., Sudo H., Fukushima E. O., Akashi T., Aoki T., Saito K., Muranaka T., Plant Cell, 23, 4112-4123 (2011).

195) Ramilowski J. A., Sawai S., Seki H., Mochida K., Yoshida T., Sakurai T., Muranaka T., Saito K., Daub C. O., Plant Cell Physiol., 54, 697-710 (2013).

196) Mochida K., Sakurai T., Seki H., Yoshida T., Takahagi K., Sawai S., Uchiyama H., Muranaka T., Saito K., Plant J., 89, 181-194 (2017) .

197) Han R., Takahashi H., Nakamura M., Yoshimoto N., Suzuki H., Shibata D., Yamazaki M., Saito K., Front. Plant Sci., 6, 426 (2015) .

198) Han R., Takahashi H., Nakamura M., Bunsupa S., Yoshimoto N., Yamamoto H., Suzuki H., Shibata D., Yamazaki M., Saito K., Biol. Pharm. Bull., 38, 876-883 (2015).

199) Rai A., Yamazaki M., Takahashi H., Nakamura M., Kojoma M., Suzuki H., Saito K., Front. Plant Sci., 7, 481 (2016).

200) Rai A., Nakamura M., Takahashi H., Suzuki H., Saito K., Yamazaki M., Plant Cell Rep., 35, 2091-2111 (2016). 
201) Fukushima A., Nakamura M., Suzuki H., Yamazaki M., Knoch E., Mori T., Umemoto N., Morita M., Hirai G., Sodeoka M., Saito K., Front. Plant Sci., 7, 1883 (2016).

202) Rai A., Kamochi H., Suzuki H., Nakamura M., Takahashi H., Hatada T., Saito K., Yamazaki M., J. Nat. Med., 71, 1-15 (2017).

203) Rai A., Saito K., Curr. Opin. Biotechnol., 37, 127-134 (2016).

204) Rai A., Saito K., Yamazaki M., Plant J., 90, 764-787 (2017).

205) Albinsky D., Kusano M., Higuchi M., Hayashi N., Kobayashi M., Fukushima A., Mori M., Ichikawa T., Matsui K., Kuroda H., Horii Y., Tsumoto Y., Sakakibara H., Hirochika H., Matsui M., Saito K., Mol. Plant, 3, 125-142 (2010).

206) Kusano M., Fukushima A., Fujita N., Okazaki Y., Kobayashi M., Oitome N. F., Ebana K., Saito K., Mol. Plant, 5, 442-451 (2012).

207) Kusano M., Yang Z., Okazaki Y., Nakabayashi R., Fukushima A., Saito K., Mol. Plant, 8, 58-67 (2015).

208) Oikawa A., Matsuda F., Kusano M., Okazaki Y., Saito K., Rice, 1, 63-71 (2008).

209) Sakurai T., Kondou Y., Akiyama K., Kurotani A., Higuchi M., Ichikawa T., Kuroda H., Kusano M., Mori M., Saitou T., Sakakibara H., Sugano S., Suzuki M., Takahashi H., Takahashi S., Takatsuji H., Yokotani N., Yoshizumi T., Saito K., Shinozaki K., Oda K., Hirochika H., Matsui M., Plant Cell Physiol., 52, 265-273 (2011).

210) Suzuki M., Kusano M., Takahashi H., Nakamura Y., Hayashi N., Kobayashi M., Ichikawa T., Matsui M., Hirochika H., Saito K., Metabolomics, 6, 137-145 (2010) .

211) Kusano M., Fukushima A., Redestig H., Saito K., J. Exp. Bot., 62, 1439-1453 (2011).

212) Kusano M., Tabuchi M., Fukushima A., Funayama K., Diaz C., Kobayashi M., Hayashi N., Tsuchiya Y. N., Takahashi H., Kamata A., Yamaya T., Saito K., Plant J., 66, 456-466 (2011).

213) Toyosawa Y., Kawagoe Y., Matsushima R., Crofts N., Ogawa M., Fukuda M., Kumamaru T., Okazaki Y., Kusano M., Saito K., Toyooka K., Sato M., Ai Y., Jane J. L., Nakamura
Y., Fujita N., Plant Physiol., 170, 1255-1270 (2016).

214) Yang Z., Nakabayashi R., Mori T., Takamatsu S., Kitanaka S., Saito K., Chem. Pharm. Bull., 64, 952-956 (2016) .

215) Masumoto C., Miyazawa S., Ohkawa H., Fukuda T., Taniguchi Y., Murayama S., Kusano M., Saito K., Fukayama H., Miyao M., Proc. Natl. Acad. Sci. USA, 107, 52265231 (2010).

216) Saika H., Oikawa A., Matsuda F., Onodera H., Saito K., Toki S., Plant Physiol., 156, 1269-1277 (2011).

217) Saika H., Oikawa A., Nakabayashi R., Matsuda F., Saito K., Toki S., Metabolites, 2, 1123-1138 (2012).

218) Matsuda F., Okazaki Y., Oikawa A., Kusano M., Nakabayashi R., Kikuchi J., Yonemaru J., Ebana K., Yano M., Saito K., Plant J., 70, 624-636 (2012).

219) Redestig H., Kusano M., Ebana K., Kobayashi M., Oikawa A., Okazaki Y., Matsuda F., Arita M., Fujita N., Saito K., BMC Syst. Biol., 5, 176 (2011).

220) Matsuda F., Nakabayashi R., Yang Z., Okazaki Y., Yonemaru J., Ebana K., Yano M., Saito K., Plant J., 81, 13-23 (2015).

221) Kurusu T., Koyano T., Hanamata S., Kubo T., Noguchi Y., Yagi C., Nagata N., Yamamoto T., Ohnishi T., Okazaki Y., Kitahata N., Ando D., Ishikawa M., Wada S., Miyao A., Hirochika H., Shimada H., Makino A., Saito K., Ishida H., Kinoshita T., Kurata N., Kuchitsu K., Autophagy, 10, 878888 (2014).

222) Kusuda H., Koga W., Kusano M., Oikawa A., Saito K., Hirai M. Y., Yoshida K. T., Plant Sci., 232, 49-56 (2015).

223) Maruyama K., Urano K., Yoshiwara K., Morishita Y., Sakurai N., Suzuki H., Kojima M., Sakakibara H., Shibata D., Saito K., Shinozaki K., Yamaguchi-Shinozaki K., Plant Physiol., 164, 1759-1771 (2014).

224) Selvaraj M. G., Ishizaki T., Valencia M., Ogawa S., Dedicova B., Ogata T., Yoshiwara K., Maruyama K., Kusano M., Saito K., Takahashi F., Shinozaki K., Nakashima K., Ishitani M., Plant Biotechnol. J., 15, 1465-1477 (2017). 
225) Tawaraya K., Horie R., Saito A., Shinano T., Wagatsuma T., Saito K., Oikawa A., J. Plant Nutr., 36, 1138-1159 (2013).

226) Kusano M., Redestig H., Hirai T., Oikawa A., Matsuda F., Fukushima A., Arita M., Watanabe S., Yano M., Hiwasa-Tanase K., Ezura H., Saito K., PLoS One, 6, e16989 (2011).

227) Kusano M., Baxter I., Fukushima A., Oikawa A., Okazaki Y., Nakabayashi R., Bouvrette D. J., Achard F., Jakubowski A. R., Ballam J. M., Phillips J. R., Culler A. H., Saito K., Harrigan G. G., Metabolomics, 11, 261-270 (2015).

228) Lawrence S., Nat. Biotechnol., 24, 380 (2006).

229) Taroncher-Oldenburg G., Marshall A., Nat. Biotechnol., 25, 961 (2007).

230) Thomson Reuters. "Kazuki Saito \& Masami Yokota Hirai talk with ScienceWatch.com and answer a few questions about this month's Fast Breaking Paper in the field of Plant \& Animal Science.': 〈http://archive.science watch.com/dr/fbp/2008/08junfbp/08junfbp Hirai_Sa/ $>$, cited 26 August, 2017.

231) Clarivate Analytics. "Highly Cited Researchers.": 〈http://hcr.stateofinnovation.com/〉, cited 26 August, 2017.

232) American Society of Plant Biologists. "Recognizing Our Authors.'’:〈http://aspb.org/pub lications / aspb-journals / aspb-top-authors / $\rangle$, cited 26 August, 2017.

233) Tu Y., Nat. Med., 17, 1217-1220 (2011).

234) Bachmann B. O., Van Lanen S. G., Baltz R. H., J. Ind. Microbiol. Biotechnol., 41, 175184 (2014).

235) Nützmann H. W., Osbourn A., Curr. Opin. Biotechnol., 26, 91-99 (2014).

236) Nakayasu M., Umemoto N., Ohyama K., Fujimoto Y., Lee H. J., Watanabe B., Muranaka T., Saito K., Sugimoto Y., Mizutani M., Plant Physiol., 175, 120-133 (2017).
237) Itkin M., Heinig U., Tzfadia O., Bhide A. J., Shinde B., Cardenas P. D., Bocobza S. E., Unger T., Malitsky S., Finkers R., Tikunov Y., Bovy A., Chikate Y., Singh P., Rogachev I., Beekwilder J., Giri A. P., Aharoni A., Science, 341, 175-179 (2013).

238) Owen C., Patron N. J., Huang A., Osbourn A., Curr. Opin. Chem. Biol., 40, 24-30 (2017).

239) Reed J., Stephenson M. J., Miettinen K., Brouwer B., Leveau A., Brett P., Goss R. J. M., Goossens A., O'Connell M. A., Osbourn A., Metab. Eng., 42, 185-193 (2017).

240) Sawai S., Ohyama K., Yasumoto S., Seki H., Sakuma T., Yamamoto T., Takebayashi Y., Kojima M., Sakakibara H., Aoki T., Muranaka T., Saito K., Umemoto N., Plant Cell, 26, 3763-3774 (2014).

241) Nonaka S., Arai C., Takayama M., Matsukura C., Ezura H., Sci. Rep., 7, 7057 (2017).

242) Westfall P. J., Pitera D. J., Lenihan J. R., Eng D., Woolard F. X., Regentin R., Horning T., Tsuruta H., Melis D. J., Owens A., Fickes S., Diola D., Benjamin K. R., Keasling J. D., Leavell M. D., McPhee D. J., Renninger N. S., Newman J. D., Paddon C. J., Proc. Natl. Acad. Sci. USA, 109, E111-E118 (2012).

243) Galanie S., Thodey K., Trenchard I. J., Filsinger Interrante M., Smolke C. D., Science, 349, 1095-1100 (2015).

244) Ministry of the Environment, Government of Japan. "Access to Genetic Resource and the Fair and Equitable Sharing of Benefits Arising from their Utilization."':〈http://www.env.go. $\mathrm{jp} /$ nature/biodic-abs/index.html $\rangle$, cited 26 August, 2017.

245) Okada T., Afendi F. M., Yamazaki M., Chida K. N., Suzuki M., Kawai R., Kim M., Namiki T., Kanaya S., Saito K., J. Nat. Med., 70, 107-114 (2016). 